Chicago-Kent College of Law

Scholarly Commons @ IIT Chicago-Kent College of Law

All Faculty Scholarship

Faculty Scholarship

December 2010

\title{
United States - Definitive Anti-Dumping and Countervailing Duties on Certain Products from China
}

Sungjoon Cho

IIT Chicago-Kent College of Law, scho1@kentlaw.iit.edu

Follow this and additional works at: https://scholarship.kentlaw.iit.edu/fac_schol

Part of the International Trade Law Commons

\section{Recommended Citation}

Sungjoon Cho, United States - Definitive Anti-Dumping and Countervailing Duties on Certain Products from China, (2010).

Available at: https://scholarship.kentlaw.iit.edu/fac_schol/185

This Brief is brought to you for free and open access by the Faculty Scholarship at Scholarly Commons @ IIT Chicago-Kent College of Law. It has been accepted for inclusion in All Faculty Scholarship by an authorized administrator of Scholarly Commons @ IIT Chicago-Kent College of Law. For more information, please contact jwenger@kentlaw.iit.edu, ebarney@kentlaw.iit.edu. 


\section{BEFORE THE APPELLATE BODY OF THE WORLD TRADE ORGANIZATION}

\section{UNITED STATES - DEFINITIVE ANTI-DUMPING AND COUNTERVAILING DUTIES ON CERTAIN PRODUCTS FROM CHINA (WT/DS379/R)}

\section{AMICUS CURIAE SUBMISSION BY SUNGJ OON CHO}

DECEMBER 14, 2010 


\section{Introduction}

1. Recognizing the legal authority of the Appellate Body to accept and consider an unsolicited amicus curiae submission, ${ }^{1}$ I respectfully submit this brief through the Appellate Body Secretariat.

2. In United States - Definitive Anti-Dumping and Countervailing Duties on Certain Products from China (WT/DS 379/R), the panel's interpretation of relevant provisions of the General Agreement on Tariffs and Trade (GATT) and Agreement on Subsidies and Countervailing Measures (SCM), in particular GATT Article VI and SCM Articles 19:4 and $12: 8$, is misguided. ${ }^{2}$

3. The panel's interpretation has two fundamental flaws. First, the panel disregards the general illegality of double remedies under the WTO norms, which is manifest under GATT Article VI and SCM Article 19:4. As a result, the panel validates the U.S.' concurrent imposition of countervailing duties after the previous imposition of antidumping duties under the non-market economy (NME) methodology. Second, the panel, blatantly disregarding SCM provisions, such as Article 12.8, shifts the burden of proof from the investigating authority (the United States Department of Commerce (DOC) in this dispute) to the respondents. Although the investigating authority is required under the Article to fully demonstrate the non-existence of double counting when it employs the NME methodology, the panel nonetheless imposes on respondents the burden of establishing that there existed actual double counting, and therefore "duties in excess of the subsidy."

\section{Background}

4. WTO rules prohibit its members from imposing both antidumping and countervailing duties concurrently when one of those measures has already rectified alleged unfair trade practices. Otherwise, the WTO would have permitted "double remedies" in the sense that an importing country could remedy the same unfair trade situation as to the same imported product twice. GATT Article VI:5 illustrates this discipline in case of "export subsidization."

5. In the past, the DOC had complied with the prohibition on double remedies. Until 2007, the DOC had not imposed countervailing duties on imported products from NME countries when it imposed antidumping duties on the same products using the NME methodology. Under the NME methodology, the DOC uses surrogate values from third-

\footnotetext{
${ }^{1}$ Appellate Body Report, United States - Imposition of Countervailing Duties on Certain Hot-Rolled Lead and Bismuth Carbon Steel Products Originating in the United Kingdom, WT/DS138/AB/R, adopted 7 J une 2000, ๆๆ 39, 42; Appellate Body Report, European Communities - Trade Description of Sardines, WT/ DS231/AB/ R, adopted 23 October 2002, ๆๆ 157, 160.

2 United States - Definitive Anti-Dumping and Countervailing Duties on Certain Products from China, WT/ DS 379/R, Panel Report circulated on October 22, 2010 [hereinafter Panel Report].
} 
party countries instead of actual home market values of respondents' countries in calculating normal values of these products. The DOC had refused to impose both antidumping and countervailing duties simultaneously in this situation on the ground that doing so would constitute double remedies. The DOC had concluded that replacing subsidy-prone actual home market values from an NME exporting country with subsidy-free surrogate values from third-party countries would deprive it of any grounds for an additional trade remedy via countervailing measures. The U.S. Court of International Trade and an independent public research agency, the Government Accounting Office (GAO), have both recently reaffirmed this position. ${ }^{3}$

6. However, the DOC has recently departed from this long-standing position and begun to impose both countervailing and antidumping duties on the same imported goods from NME countries. The DOC appears to attribute this policy change to the fact that "market forces actually determine the prices of more than $90 \%$ of products in China." 4 Yet without according China a market economy status, the DOC instead began simply to impose countervailing duties on Chinese imports in addition to previously imposed antidumping duties. USCIT rejected the DOC's new policy as an "unreasonable" interpretation of the U.S. subsidy statute, including provisions such as 19 U.S.C. § 1671, that permits the DOC to impose a countervailing duty only when there is a "countervailable subsidy with respect to the manufacture, production, or export of a class or kind of merchandise imported ... into the United States." 5 The current dispute before the panel involves the DOC's four investigations since it adopted the new position. ${ }^{6}$

\section{Legal Issues at Stake}

7. Although the U.S. (the DOC) acknowledges in this dispute that simultaneously imposing antidumping and countervailing duties on products imported from NME countries may create a double remedies problem, it argues that this may not occur in some circumstances and that, in any event, it has neither the authority ${ }^{7}$ nor the capability $^{8}$ to avoid the problem. In sum, the DOC justifies its recent departure from its old stance by relying on the uncertainty of double remedies occurring when an NME methodology is used.

\footnotetext{
3 U.S. Government Accountability Office, "U.S. - China Trade: Commerce Faces Practical and Legal Challenges in Applying Countervailing Duties," GAO-05-474 (J une 2005) [hereinafter GAO Report].

${ }^{4}$ Congressional Research Service (CRS), Trade Remedy Legislation: Applying Countervailing Action to Nonmarket Economy Countries, Apr. 19, 2007, at 17.

519 U.S.C. § 1671(a)(1)

${ }^{6}$ Panel Report, supra note 2, $\mathbb{1} 14.4$ ("Thus, the four countervailing duty investigations at issue in the present dispute constitute the first instances of imposition by the USDOC of countervailing duties on imports from an NME.")

${ }^{7}$ Id., 914.6 "the USDOC indicated that it had no authority to address the issue of double remedies in the context of countervailing duty investigations."

${ }^{8}$ GPX International Tire Corporation v. United States (United States Court of International Trade), Slip Op. 10-84, Aug. 4, 2010, at 3 [hereinafter CPX II].
} 
8. Indeed, the DOC, despite the fact that it was an investigating authority in four cases concerning this dispute, failed to demonstrate that double remedies would not occur in these four cases, using an NME methodology, if it imposed both countervailing and antidumping duties on the same products. The DOC argued instead that respondents bear the burden of demonstrating that double remedies actually occurred in these cases. And despite the fact that the United States Court of International Trade (USCIT) had invalidated this interpretation as "unreasonable," 9 the panel agrees with the DOC in this dispute. In doing so, the panel disregards WTO subsidy disciplines under GATT Article VI and SCM Articles 12:8 and 19:4.

9. In the following two sections, I explain why the panel's reasoning is flawed from both a substantive and a procedural standpoint.

\section{A. The Panel Misinterprets GATT Article VI and SCM Article 19:4 as to the DOC's Substantive Obligation Not to Generate Double Remedies}

\section{(i) Double Remedies Are Inconsistent with the WTO Subsidy Norms}

10. First, the panel itself acknowledges the general possibility of double remedies from the adoption of an NME methodology:

14.67. [W] have no difficulty accepting the general proposition that the use of an NME methodology likely provides some form of remedy against subsidisation, and therefore, that the simultaneous imposition of anti-dumping duties calculated under an NME methodology and of countervailing duties likely results in any subsidy granted in respect of the good at issue being offset more than once. (emphasis added)

14.69. (...) Expressed differently, the dumping margin calculated under an NME methodology generally is higher than would be the case otherwise because it results from a comparison of the export price to market-determined, and hence unsubsidized, costs of production, rather than to the producer's actual, subsidized (or distorted) costs of production. (emphasis added)

14.70. [T] he anti-dumping duties calculated under an NME methodology will remedy both dumping and subsidization. (...) [T] he subsidy is likely to be "offset" more than once, i.e., once through the anti-dumping duty, and again at least partially through the countervailing duty. For this reason, we consider that the concurrent imposition of anti-dumping duties calculated under an NME methodology and of countervailing duties creates the potential for imposition of a "double remedy", as China defines this term.

9 GPX International Tire Corporation v. United States (United States Court of International Trade), Slip Op. 09-103, Sep. 18, 2009, at 13, 19 [hereinafter CPX I]. 
11. Moreover, as the panel admits, the GAO and the USCIT have also affirmed the potential for a double remedy problem when an NME methodology is used. ${ }^{10}$ In fact, the "NME AD statute was designed to remedy the inability to apply the CVD law to NME countries, so that subsidization of a foreign producer or exporter in an NME country was addressed through the NME AD methodology." 11 To be more precise, under the $\mathrm{NME} A \mathrm{D}$ methodology, the export price is compared with the "subsidy-free" home market price, which is constructed through the third-party country price (surrogate value). Therefore, it is only logical that the imposition of an additional countervailing duty in this situation leads to a double remedy without some adjustment. 12

12. The GAO's opinions and the U.S. court rulings on this issue are not binding in the sense that the panel must rely on them to resolve this dispute. Nonetheless, they make clear the errors in the panel's reasoning on the identical issues.

13. As is evident in the U.S. court rulings, a double remedy, manifested in the imposition of countervailing measure with the simultaneous imposition of the NME antidumping measure, is equivalent to the imposition of countervailing duty when there is no subsidy to be countervailed in the first place. ${ }^{13}$ This is a blatant violation of the most

fundamental subsidy discipline of the WTO system. GATT Article VI:3 provides that:

No countervailing duty shall be levied on any product of the territory of any contracting party imported into the territory of another contracting party in excess of an amount equal to the estimated bounty or subsidy determined to have been granted, directly or indirectly, on the manufacture, production or export of such product in the country of origin or exportation. (emphasis added)

14. Here, GATT Article VI:3 clearly prohibits a WTO member from imposing any countervailing duty when there is no subsidy "determined to have been granted," and no subsidy was left to be determined in this case. . Likewise, Article 19.4 of the SCM provides that:

No countervailing duty shall be levied on any imported product in excess of the amount of the subsidy found to exist, calculated in terms of subsidization per unit of the subsidized and exported product. (emphasis added)

15. In this dispute, the NME AD methodology effectively offset any subsidization to be countervailed, and consequently no subsidy was found to exist. Therefore, no

\footnotetext{
10 Panel Report, supra note 2, ๆ 14.72 ("The GAO Report concludes, on this basis, that economic theory suggests that there is a substantial potential for domestic subsidies to be "double counted" in the event that the USDOC applied countervailing duties to NME country products while continuing to use surrogate country values to calculate anti-dumping duties on those same products. The decision of the U.S. Court of International Trade in GPX is based on a similar theoretical foundation - in fact, the Court cites to the GAO Report in support of its finding that without some type of adjustment being made, the concurrent imposition of anti-dumping duties and of countervailing duties with respect to Chinese products could very well result in a double remedy.")

${ }^{11} \mathrm{CPX}$ I, supra note 9, at 16.

12 Id., at 17.

${ }^{13}$ Panel Report, supra note 2, $\uparrow 14.110$.
} 
countervailing duty should have been imposed in this situation. Therefore, the DOC's imposition of countervailing duties in the four investigations in question is inconsistent with Article 19 of the SCM. ${ }^{14}$

\section{(ii) The Panel's Interpretation Is Misguided since It Permits Double Remedies}

16. The panel supports the U.S. position that essentially denies any connection between antidumping and countervailing duties in the WTO system. This denial of a remedial nexus, in particular when an antidumping authority uses an NME methodology as in this dispute, paves the way for the imposition of double remedies. The U.S. argues that "anti-dumping and countervailing duties are two distinct instruments, meant to address different kinds of harm."15 Likewise, it contends that an MNE methodology "does not somehow transform the anti-dumping duty itself into a countervailing duty." 16

17. Endorsing the U.S. position, the panel also refuses to apply the WTO subsidy disciplines to the double remedy situation. The panel holds that the SCM, Article 19.4 in particular, is "unrelated" to an NME methodology and thus, the double remedy problem. The panel rules that:

14.112. [B]y its own terms, Article 19.4 of the SCM Agreement is oblivious to any potential concurrent imposition of anti-dumping duties. Hence, that an antidumping duty calculated under a methodology may have the effect of "offsetting" a subsidy in totality or in part has no effect on the existence of the subsidy which, under Article 1 of the SCM Agreement, depends on the existence of a financial contribution and of a benefit; nor would it have an effect on the amount of the subsidy which, under Article 14 of the SCM Agreement, must be determined by reference to the marketplace. In sum, the narrowly-crafted discipline contained in Article 19.4 of the SCM Agreement does not address situations of "double remedies". (emphasis added)

14.117. [B]y its very terms, Article VI:5 of the GATT 1994 is limited to "situation[s] of [...] export subsidization". In our view, these terms are selfexplanatory in their intention to limit the scope of the prohibition in Article VI:5 to situations involving export subsidies, to the exclusion of situations in which domestic subsidies are granted on exported goods. Such a narrow reading of the terms "situation of [...] export subsidization" is supported by the context to Article VI:5, and in particular by the distinction made between domestic vs. export subsidies in Article VI:3 of the GATT 1994, which deals with countervailing duties, and by the separate treatment accorded to export subsidies under Article XVI of the GATT 1994. (emphasis added)

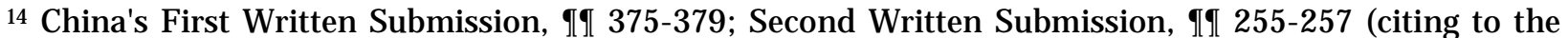
Panel Report on US - Countervailing Measures on Certain EC Products, I 8.1(a), and Appellate Body Report on US - Countervailing Measures on Certain EC Products, ๆ 161(a)).

15 United States First Written Submission, ๆศ 389-394.

${ }^{16}$ Panel Report, supra note 2, ๆ 14.91.
} 
14.122. (...) We view China's argument as implying that it is the object and purpose of the SCM Agreement to impose disciplines not only with respect to the use of countervailing duties, but also of anti-dumping duties. As explained above, we are of the view that the object and purpose of Part V of the SCM Agreement is limited to imposition of disciplines with respect to the former. (emphasis added)

18. The panel's approach is a strikingly narrow interpretation of so fundamental a subsidy discipline as Article 19.4. This Article contains no express language that permits an investigating authority to disregard a double remedy situation. As a result of its narrow interpretation, the panel deprives the SCM of a necessary discipline over an NME situation as it fails to recognize a critical remedial nexus between antidumping and countervailing measures under the WTO system.

19. First of all, the panel's interpretation is flatly inconsistent with GATT Article VI:5, which establishes a remedial nexus between antidumping and countervailing measures. Article VI:5 provides that:

"No product of the territory of any contracting party imported into the territory of any other contracting party shall be subject to both anti-dumping and countervailing duties to compensate for the same situation of dumping or export subsidization." (emphasis added)

The drafters of Article VI:5 clearly intended to avoid double remedies in general ("both anti-dumping and countervailing duties to compensate for the same situation"), be it "export subsidization," which the panel does single out, or "dumping," which certainly connotes an NME methodology, as in this dispute.

20. The simultaneous imposition of both antidumping and countervailing duties with the use of an NME methodology tends to generate the same adjustment problem that occurs with the imposition of both antidumping and countervailing duties over export subsidies. The GAO found that "[t]here is substantial potential for double counting of domestic subsidies if Commerce applies CVDs to China while continuing to use its current NME methodology to determine [ADs]."17 As J apan rightly observed, export subsidization is just an "expression of an underlying principle that an importing Member may not impose a double remedy against the same subsidy," rather than of an exclusive example for a double remedy situation. ${ }^{18}$ In sum, both occasions - export subsidies and the NME methodology - involve the same mathematical challenges under which an investigating authority should avoid any double counting.

21. The U.S. court has also held that the NME antidumping and CVD statutes work together "to counteract any unfair advantage gained by government intervention" and "to correct governmental distortion of market prices." 19 With this remedial nexus in mind, the USCIT rejected the DOC's argument that "[t]he AD and CVD laws provide

17 GAO Report, supra note 4, at 33.

${ }^{18} \mathrm{~J}$ apan Third-Party Submission, ๆศ 3-14 (emphasis added).

${ }_{19}$ CPX I, supra note 9, at 12-13. 
separate remedies for separate unfair trade practices" and that "the classification of China as an NME under the $\mathrm{AD}$ law does not have any necessary consequence under the CVD law."20

\section{(iii) The "Prior Existence and Demise" Argument Is without Merits}

22. Finally, the panel justifies its refusal to address the double remedy situation via the SCM Article 19.4 based on the so-called "prior existence and demise" of a provision under the Tokyo Round Subsidies Code. The panel emphasizes that any provision equivalent to Article 15 of the Tokyo Round Subsidies Code, which had explicitly addressed the double remedy in case of an NME methodology, cannot be found in the current SCM. Citing the Appellate Body (AB) Report in U.S. - Underwear, the panel concludes that the prior existence and demise of Article 15 of the Tokyo Round Subsidies Code would constitute a "context" within the meaning of Article 31 of the Vienna Convention on the Law of Treaties. ${ }^{21}$ According to the panel, this context reveals the intention of the SCM's drafters not to address the double remedy issue with an NME methodology. The panel makes a similar inference from the silence in addressing the double remedy issue under China's Accession Protocol. ${ }^{22}$

23. However, the panel's interpretation reads too much into the AB Report. First of all, the same $\mathrm{AB}$ report that the panel invokes (U.S. - Underwear) unequivocally confirmed that:

We are not entitled to assume that that disappearance was merely accidental or an inadvertent oversight on the part of either harassed negotiators or inattentive draftsmen. That no official record may exist of discussions or statements of delegations on this particular point is, of course, no basis for making such an assumption. ${ }^{23}$

24. In that report, the $\mathrm{AB}$ in fact strongly warned against drawing too many inferences, without any affirmative evidence, from the non-existence of a particular provision which had existed in a previous, related legal document. No doubt, this warning applies unreservedly to the factual pattern of this dispute.

25. As a matter of fact, in stark contrast with the panel's inference, the $A B$ has not hesitated to rule on those issues whose disciplines are not explicitly manifest in the WTO provisions. For example, the Anti-Dumping Code on its face neither endorses nor prohibits the practice of "zeroing." Nonetheless, in a series of well-crafted decisions, the $\mathrm{AB}$ has unwaveringly invalidated this practice. ${ }^{24}$ In addition, the $\mathrm{AB}$ has imposed

\footnotetext{
20 Id., at 13-14.

${ }^{21}$ Panel Report, supra note 2, ๆ 14.120, n. 1027.

22 Id., ๆ 14.121 ("Rather, we merely note the absence of any provision addressing the question of "double remedy" in China's Protocol of Accession. In our view, such an absence again suggests that the drafters of Article 19.4 of the SCM Agreement did not intend this provision to address the issue of double remedies.").

23 Appellate Body Report, United States - Restrictions on Imports of Cotton and Man-made Fibre Underwear, WT/ DS24/AB/R, adopted on Feb. 25, 1997, at 16.

${ }^{24}$ See generally Sungjoon Cho, Global Constitutional Lawmaking, 31 U. PA. J . INT’L L. 621 (2010).
} 
effective disciplines on many other subsidy issues, such as the "'privatization" (effect of a privatization of state-owned assets on previously-conferred subsidies) and "passthrough" (treatment of subsidies conferred upon upstream inputs)," despite the absence of any express textual provision. ${ }^{25}$ For these reasons, the panel's inference from the textual silence cannot be accepted.

26. Moreover, U.S. - Underwear involved an entirely different legal relationship between the previous and subsequent agreements, which militates against applying its reasoning. In U.S. - Underwear, the subsequent agreement (the Agreement on Textiles and Clothing (ATC)) was created to override the previous Multi-Fiber Agreement (MFA), which had been condemned as highly protectionist. Therefore, one should not be surprised to see that many of the MFA provisions had disappeared in the new ATC. In fact, that is exactly why the ATC replaced the MFA. In contrast, the SCM was not created to override the Tokyo Round Subsidies Code. On the contrary, the SCM evolved from the Tokyo Round Subsidies Code.

27. In sum, the DOC's simultaneous imposition of countervailing duties when it had already imposed antidumping duties on the same imported products using an MNE methodology constitutes a double remedy, which is inconsistent with GATT Articles VI:3 and VI:5, as well as Article 19.4 of the SCM.

\section{B. The Panel Disregards the DOC's Procedural Obligation to Inform Interested Parties of the Essential Facts Supporting Its Determination under SCM Article 12.8}

28. The U.S. characterizes the occurrence of double remedies with the simultaneous imposition of countervailing and antidumping duties with an NME methodology as depending on "special factual circumstances." 26 In doing so, the U.S. argues that it is the respondents, not the investigating authority, that must prove the "precise amount of a subsidy attributed to the imported products under investigation." 27 According to the U.S., interested parties and China had failed to "establish[] the existence of a double remedy, and in particular had not provided sufficient evidence." 28

\footnotetext{
${ }_{25}$ Panel Report, supra note 2, ๆ 14.84 .

26 Id., ๆ 14.45 ("[T]he United States submits counter-examples to demonstrate that in some instances, the surrogate values used by the USDOC in its dumping margin calculation were in fact lower than both the producer's actual costs and the benchmarks used by the USDOC in its calculation of the amount of the subsidy.") (emphasis added); id., ๆ 14.75 ("In sum, the United States' arguments raise the question of the extent of a double remedy in specific factual circumstances - whether a complete double remedy necessarily results from all instances of concurrent imposition of anti-dumping duties calculated under an NME methodology and of countervailing duties. They do not, however, invalidate the general proposition that at least some double remedy will likely arise from the concurrent imposition of countervailing duties and anti-dumping duties calculated under an NME methodology.") (emphasis added).

27 Id., 914.77.

28 Id., ๆ 14.6.
} 
29. As discussed above, the simultaneous imposition of antidumping and countervailing with the use of an NME methodology violates the WTO subsidy norms if it generates double remedies. Nonetheless, the U.S. denies a violation by arguing that its simultaneous imposition of countervailing duties in the four investigations at issue may not necessarily entail double remedies. According to the U.S., one cannot assume that "replacement of actual (subsidized) values of factor inputs with surrogate values under the NME methodology results in an increase in the normal value by an amount that is equal to or greater than the amount of the subsidy" and that "the normal value arrived at using the NME calculation is, in every instance, completely insulated from any of the effects of the countervailed subsidy."29

30. The panel appears to side with the U.S. position here. It holds that:

14.147. We have sympathy for the United States' argument that it is for interested parties who seek to convince an investigating authority to modify its application of its trade remedy laws (especially where that application has not been shown to be WTO-inconsistent) to bring relevant evidence to the investigating authority. (emphasis added)

14.180. By contrast, while we have found above that the use of a surrogate value in principle reflects the use of unsubsidized costs, we also have indicated that the precise extent to which the NME calculation captures any subsidization is a factual issue which it could be difficult to ascertain. (emphasis added)

31. However, Article VI:3 of the GATT provides:

No countervailing duty shall be levied on any product of the territory of any contracting party imported into the territory of another contracting party in excess of an amount equal to the estimated bounty or subsidy determined to have been granted, directly or indirectly, on the manufacture, production or export of such product in the country of origin or exportation. (emphasis added)

32. Likewise, Article 11.2 of the SCM provides in part:

The application shall contain such information as is reasonably available to the applicant on the following:

(..)

(iii) evidence with regard to the existence, amount and nature of the subsidy in question;

(iv) evidence that alleged injury to a domestic industry is caused by subsidized imports through the effects of the subsidies; this evidence includes information on the evolution of the volume of the allegedly subsidized

${ }^{29}$ Id., ๆ 14.55. 
imports, the effect of these imports on prices of the like product in the domestic market and the consequent impact of the imports on the domestic industry, as demonstrated by relevant factors and indices having a bearing on the state of the domestic industry, such as those listed in paragraphs 2 and 4 of Article 15. (emphasis added).

33. Article 12.8 of the SCM Agreement also provides:

The authorities shall, before a final determination is made, inform all interested Members and interested parties of the essential facts under consideration which form the basis for the decision whether to apply definitive measures. (emphasis added)

34. Finally, Article 14 of the SCM provides that:

For the purpose of Part V, any method used by the investigating authority to calculate the benefit to the recipient conferred pursuant to paragraph 1 of Article 1 shall be provided for in the national legislation or implementing regulations of the Member concerned and its application to each particular case shall be transparent and adequately explained. (emphasis added)

35. These provisions, read together, impose two basic procedural obligations on any investigating authority, such as the DOC, when it applies countervailing duties simultaneously with the imposition of antidumping duties using an NME methodology. First, it must prove the existence of, and calculate the amount of, an alleged subsidy (grant) despite the potential existence of double remedies; second, it must provide respondents with an adequate explanation of how it discovered the subsidy to be countervailed, i.e., the calculation methodology. Importantly, these basic obligations allocate the initial proof burden to the investigating authority. In other words, an investigating authority, such as the DOC in this dispute, must establish a prima facie case that a subsidy to be countervailed does exist, and the amount of that subsidy, even under the double remedy situation. The WTO jurisprudence also firmly upholds this obligation. ${ }^{30}$

36. Therefore, both the U.S. and the panel depart from the fundamental procedural obligation that an investigating authority must demonstrate the existence and the amount of subsidy at issue. The panel's position ignores the U.S.' obligations as an investigating authority under the GATT and the SCM to adhere to a fair and equitable investigation process and inform respondents of detailed justifications for its final determination.

37. At the same time, the panel's position upholding the U.S.' view unduly shifts the general burden of proof in a subsidy dispute from the investigating authority to the respondent, despite the panel's own initial observation that the DOC itself has

30 Id., ๆ 14.111. See also id., ๆ 14.77, n. 977 (concerning an investigating authority’s to "establish[] whether, and in what amount" there exists a subsidy to be countervailed). 
recognized the potential existence of a double remedy in case of the concurrent use of antidumping and countervailing measures on imported products from China. As a U.S. court held in striking down the DOC's position, this imposes an insurmountable burden on the respondent:

Commerce cannot avoid addressing an important aspect of the problem caused by applying CVD and AD methodologies to goods from NME countries by placing the burden to demonstrate double counting on GPX, because there is likely no way for any respondent to accurately prove what may very well be occurring. ${ }^{31}$

If Commerce now seeks to impose CVD remedies on the products of NME countries as well, Commerce must apply methodologies that make such parallel remedies reasonable, including methodologies that will make it unlikely that double counting will occur. The court finds that it was unreasonable for Commerce to require GPX to submit specific evidence that a double remedy of a particular amount actually was imposed on its products when parallel NME AD and CVD procedures were utilized. 32

38. As the USCIT rightly held, it is the U.S. that must prove the four investigations at issue would not constitute a double remedy situation-that, for example, "the surrogate values used by the DOC in its dumping margin calculation were in fact lower than both the producer's actual costs and the benchmarks used by the DOC in its calculation of the amount of the subsidy."33

39. Importantly, however, such proof appears to be practically infeasible, as the DOC tacitly admitted. First, it had conceded that "Congress provided no adjustment for CVDs imposed by reason of domestic subsidies in NME proceedings." 34 Then, it had failed to respond to the USCIT's remand instruction to "use improved methodologies to determine whether, and to what degree, double counting occurs when NME antidumping remedies are imposed on the same good." 35 Therefore, as the USCIT aptly observed, the only option left to the DOC must be to withdraw the imposition of the countervailing measure on the NME products. ${ }^{36}$

40. Finally, it should be noted that any anecdotal factual exception to a general rule, which forms a central theme of the U.S. argument in this dispute, neither negates the existence of the rule nor lifts the burden imposed on the investigating authority. As the EC observed, the fact that "there may be cases where export subsidies have no measurable impact on export price, or have no discernable impact on prices at all" does not undo the general rule prohibiting a double remedy to export subsidies. ${ }^{37}$

${ }^{31}$ CPX I, supra note 9, at 18 (emphasis added).

32 Id., at 19 (emphasis added).

33 Panel Report, supra note 2, ๆ 14.56.

34 Id., ๆ 14.6, n. 874.

35 CPX II, supra note 8, at 3.

36 Id.

${ }^{37}$ European Communities Third-Party Submission, ๆศा 53, 56. 
41. This interpretation is consistent with the AB's well-documented zeroing jurisprudence. When the AB struck down the DOC's zeroing practice in various forms, it highlighted the structural illegality of such practice (zeroing), rather than factual, calculative circumstances whose eventual outcome might or might not lead to an actual zeroing. For example, the AB has previously indicated that "when investigating authorities use a zeroing methodology (...) to calculate a dumping margin, whether in original investigations or otherwise, that methodology will tend to inflate the margins calculated. ${ }^{38}$ Similarly, it held that "zeroing means, in effect, that at least in the case of some export transactions, the export prices are treated as if they were less than what they actually are." 39 Therefore, the AB rejected the U.S.'s attempt to shift the burden to the complaining party to demonstrate "how the use of zeroing necessarily caused the volume of dumped imports to be inflated." 40

42. In sum, by failing to substantiate the existence of subsidization and its amount, the DOC violated its basic procedural obligation as the investigating authority under the WTO subsidy norms. At the same time, the U.S., and the panel which upholds the U.S. position, wrongly shifts the burden of proof on these critical probative issues from the investigating authority to respondents.

\section{Conclusion}

43. The DOC's simultaneous imposition of countervailing duties when it had already imposed antidumping duties on the same imported products using an MNE methodology constitutes a double remedy, which is inconsistent with GATT Articles VI:3 and VI:5, as well as Article 19.4 of the SCM.

44. In addition, by failing to substantiate the existence of subsidization and its amount, the DOC violated its basic procedural obligation as the investigating authority under the WTO subsidy norms. In upholding the U.S. position, the panel wrongly shifts the burden of proof as to these probative issues from the investigating authority to respondents.

45. In conclusion, the $A B$ must overturn the panel's ruling on the double remedies because it is inconsistent with GATT Article VI and SCM Articles 12.8 and 19.4.

\footnotetext{
${ }^{38}$ Appellate Body Report, United States - Sunset Review of Anti-Dumping Duties on Corrosion-Resistant Carbon Steel Flat Products from Japan, WT/DS244/AB/R, adopted on J an. 9, 2004, ๆ 135 (emphasis added).

39 Appellate Body Report, United States - Final Dumping Determination on Softwood Lumber from Canada, WT/ DS264/AB/ R, adopted on Aug. 31, 2004, ๆ 101 (emphasis added).

40 Panel Report, United States - Laws, Regulations and Methodology for Calculating Dumping Margins

("Zeroing"), WT/ DS294/ R, adopted on May 9, 2006 (as modified by the Appellate Body), ๆ 4.120.
} 